\title{
Medullary nephrocalcinosis in an adult patient with idiopathic infantile hypercalcaemia and a novel CYP24A1 mutation
}

Edgar Meusburger, Axel Mündlein, Emanuel Zitt, Barbara Obermayer-Pietsch, Dieter Kotzot and Karl Lhotta

Clin Kidney J (2013) 6: 211-215. doi:10.1093/ckj/sft008

This article was published with the incorrect copyright information; the licence line should have appeared as: This is an Open Access article distributed under the terms of the Creative Commons Attribution License (http://creativecommons. org/licenses/by-nc/3.0/), which permits non-commercial reuse, distribution, and reproduction in any medium, provided the original work is properly cited. For commercial re-use, please contact journals.permissions@oup.com.

The authors apologise for this error. 